\title{
MODEL PENGEMBANGAN MUTU SUMBERDAYA GURU LEMBAGA PENDIDIKAN ISLAM
}

\author{
I Mustofa Zuhri \\ Kepala MTS Negeri 11 Jember Jawa Timur \\ cakmustofa@gmail.com
}

\begin{abstract}
Abstrak:
Pada zaman era globalisasi lembaga pendidikan Islam harus lebih menekankan pada kualitas sumber daya manusianya karena guru adalah salah satu komponen utama bagi keberhasilan proses belajar mengajar di sekolah. Mutu sekolah, khususnya mutu anak didik, mau tak mau berkaitan dengan mutu guru-gurunya yang langsung terlibat dengan anak didik di kelas. Namun, pada kenyataannya, terdapat banyak keluhkan tentang kualitas guru khususnya di lembaga pendidikan Islam. Oleh karena itu, perlu adanya strategi yang komprehensif bagi guru menjadi tenaga pendidik yang berkualitas, profesional, berkomitmen serta memiliki semangat ibadah. Penelitian ini fokus mengkaji strategi pengembangan mutu guru MAN 3 Jember. Kajian penelitian ini menggunakan perspektif fenomenologis terhadap studi kasus. Hasil penelitian ini adalah bahwa untuk mengembangkan kualitas guru, para pimpinan MAN 3 Jember perlu (1) untuk membuat, menyusun, dan merumuskan visi, misi, dan tujuan lembaga khususnya pengembangan mutu guru; (2) untuk membangun komitmen yang bernilai ibadah; (3) untuk membangun sikap dan kedisiplinan; (4) untuk merubah pola pikir dan untuk membangun karakter positif guru.
\end{abstract}

Kata kunci: Lembaga pendidikan Islam, kualitas guru, proses belajar dan pengajaran, MAN 3

Jember

\begin{abstract}
:
In the era of globalization, Islamic educational institutions have to emphasize the quality of their human resources. The teacher is one of the main characters for the success of the teaching and learning process. The quality of schools, especially the students quality, is inevitably related to the teachers concerned the students in the classroom. However, in reality, there are many complaints about teacher quality, especially in Islamic educational institutions. Therefore, it is necessary to have a comprehensive strategy for teachers to become qualified, professional, committed educators who have the spirit of worship. This study focuses on the assessment of teacher quality development strategies in MAN 3 Jember. This study uses a phenomenological perspective on a case study. As a result, for developing teacher quality in MAN 3 Jember is (1) compiling, compiling, and formulating the vision, mission, and objectives of the institution, to realize teacher quality; (2) building a commitment that has worship values; (3) building attitude and discipline; (4) changing the mindset also building the positive character of the teacher.
\end{abstract}

Keywords: Islamic Educational Institutions, Teacher Quality, Teaching and Learning Process, MAN 3 Jember

\section{PENDAHULUAN}

Pendidikan adalah usaha sadar dan terencana untuk mewujudkan suasana belajar dan proses pembelajaran agar peserta didik secara aktif mengembangkan potensi dirinya untuk 
memiliki kekuatan spiritual keagamaan, pengendalian diri, kepribadian, kecerdasan, akhlak-mulia, serta keterampilan yang diperlukan dirinya, masyarakat, bangsa dan Negara. ${ }^{1}$

Secara nasional pendidikan harus mempunyai arti yang positif bagi bangsa kita. Arti positif disini berarti pendidikan harus mampu dirasakan manfaatnya oleh masyarakat, seperti memberantas kebodohan, mengentaskan kemiskinan atau mengurangi jumlah pengangguran. Pendidikan harus bersifat integral yang mencakup ranah kognitif, afektif dan psikomotorik.

Sejalan dengan tantangan kehidupan global, pendidikan merupakan hal yang sangat penting karena pendidikan merupakan salah satu penentu sumber daya manusia (SDM). Keunggulan suatu bangsa tidak lagi ditandai dengan melimpahnya kekayaan alam, melainkan pada keunggulan sumber daya manusianya. Kualiatas/mutu SDM berkorelasi positif dengan mutu pendidikan, dan mutu pendidikan sering diindikasikan dengan kondisi yang baik, memenuhi syarat disegala komponen yang harus terdapat dalam pendidikan. Komponen-komponen tersebut adalah masukan, proses, keluaran, pendidik, tenaga kependidikan, sarana dan prasarana serta biaya.

Salah satu komponen yang dimaksud di atas adalah pendidik. Pendidik merupakan komponen yang sangat penting dalam meningkatkan mutu pendidikan di sekolah/madrasah. Pendidik juga memegang peranan sentral dalam proses belajar mengajar, oleh karena itu pendidikan disuatu lembaga pendidikan sangat ditentukan oleh kemampuan yang dimiliki oleh seorang pendidik dalam menjalankan tugasnya. ${ }^{2}$

Rendahnya kualitas pendidikan di Indonesia merupakan cerminan rendahnya kualitas sistem pendidikan nasional. Rendahnya kualitas dan kompetensi pendidik secara umum, semakin membuat laju perkembangan pendidikan belum maksimal. Pendidik kita dianggap belum memiliki profesionalitas yang baik untuk kemajuan pendidikan secara global.

Sementara fenomena yang memperhatinkan tingkat kelulusan uji kompetensi guru bersertifikaksi di Jawa Timur cukup memprihatinkan, kegiatan yang dilaksanakan tanggal 30 Juli sampai 10 Agustus 2012 dari total peserta yang mencapai 123.650 guru ternyata tingkat kelulusannya hanya 70 persen. Ini berarti ada 30 persen atau 37.095 guru peserta UKGB yang tidak lulus. ${ }^{3}$

Berdasarkan Peraturan Pemerintah (PP) Nomor 14 Tahun 2005 tentang guru dab dosen, dinyatakan bahwa salah satu kompetensi yang harus dimiliki oleh pendidik adalah kompetensi profesional. Kompetensi profesional yang dimaksud dalam hal ini merupakan kemampuan pendidik dalam penguasaan materi pelajaran secara luas dan mendalam.

\footnotetext{
${ }^{1}$ Tim Permata Press Kumpulan Undang - Undang Pendidikan, (Jakarta; Permata press ) 4

2 Mulyadi, Kepemimpinan Kepala Madrasah dalam pengembangan Budaya Mutu (Malang: Litbang Kemenag RI, 2010) 47

${ }^{3}$ Mulyadi, 43
} 
Pendidik, sebagai salah satu profesi, yang melekat dalam konteks dunia kependidikan, merupakan aspek yang selalu mewarnai khazanah perkembangan sejarah bangsa. Karena, pendidik diharapkan dapat mengambil peran nyata bagi perkembangan generasi bangsa. Dan tentunya, sebagaimana yang kita saksikan dewasa ini, peran pendidik sangat menentukan bagi pembentukan karakteristik serta moralitas generasi bangsa ini. Oleh karenanya, tuntutan terhadap pendidik pun semakin hari semakin meningkat, seiring semakin meningkatnya pengaruh globalisasi diberbagai sendi kehidupan masyarakat.

Profesionalisme pendidik pun sering dipertanyakan, dalam berbagai diskursus, seminar, diskusi terbatas, profesionalisme pendidik selalu menjadi topik yang hangat diperbincangkan. Dan berbicara mengenai profesionalisme pendidik, maka ada banyak faktor yang terkait di dalamnya, mulai dari faktor tingkat pendidikan pendidik (SDM), kondisi sosio-kultural masyarakat yang mendukung bahkan faktor ekonomi (kesejahteraan pendidik).

Berkaitan degan pentingnya pendidik dalam meningkatkan kualitas/ mutu pendidikan, Tilaar mengatakan bahwa pendidik abad 21 harus memenuhi empat kriteria yaitu (1) mempunyai kepribadian yang matang (2) menguasai ilmu pengetahuan dan tekhnologi (3) mempunyai keterampilan untuk meningkatkan minat peserta didik (4) mengembangkan profesinya secara berkesinambungan. ${ }^{4}$

Dari pendapat Tilaar tersebut tugas pendidik sangat kompleks dan penuh tantangan untuk diaplikasikan dalam profesinya, oleh karena itu pendidik dituntut untuk terus meningkatkan profesionalitasnya.

Profesi pendidik dipresentasikan sebagai sosok yang mampu digugu (dipercaya) dan ditiru (dicontoh). Profil pendidik profesional yang mampu ditiru sebagaimana diajarkan oleh Ki Hajar Dewantara, adalah pendidik yang mampu berperan dalam tiga dimensi, yaitu "ing ngarso sung tulodo, ing madyo mangun karso, tut wuri handayani".

Dalam proses intraksi edukatif, pendidik memiliki peranan dan tanggung jawab yang sangat mendasar. Figur pendidik merupakan pribadi yang sangat matang yang bertugas untuk menggali, mengarahkan dan mengoptimalkan potensi peserta didik agar berkembangnya kemampuan intelektual, emosional serta kemampuan sosial peserta didik secara optimal. Peran pendidik yang begitu besar, akan memberikan dampak pada hasil pendidikan itu sendiri, yang pada gilirannya akan menentukan tercapai atau tidaknya tujuan pendidikan yang telah dicanangkan sebelumnya. Maka tidak berlebihan jika dikatakan bahwa sebaik apapun lingkungan dan sehebat apapun kurikulum pendidikan, bila tidak dikelola oleh pendidik yang baik dan memiliki kompetensi serta semangat profesionalisme, maka tidak akan membuahkan hasil yang optimal.

\footnotetext{
4 Tila'ar, Pendidikan Abad 21 (Jakarta; Pustaka Setia ,2003) 22

${ }^{5}$ Raharjo, Bografi Singkat Ki Hajar (Jogjakarta: Arrus Media) 23
} 


\section{Model Pengembangan Mutu Sumberdaya Guru}

Peningkatan mutu pendidikan berarti peningkatan mutu sumber daya manusia. Sementara mutu pendidikan belum menggembirakan, berarti sumber daya manusia Indonesia juga belum menggembirakan. Pendidik merupakan salah satu faktor dominan dalam menciptakan sumber daya manusia yang berkompetensi dan profesional. Oleh karena itu kegagalan dalam dunia pendidikan, sering dialamatkan pada pendidik. Hal ini disebabkan karena pendidik dipandang sebagai sumber daya yang aktif dibanding dengan komponen organisasi sekolah atau madrasah lainnya seperti sarana prasarana, kurikulum yang merupakan sumber daya sekolah yang pasif, pendidik dituntut terus untuk mencerdaskan kehidupan bangsa.

Kompetensi profesional merupakan salah satu kualifikasi pendidik yang terpenting. Bila kompetensi profesional tidak ada pada diri seorang pendidik, maka akan diragukan tingkat kompetensinya dalam melakukan tugasnya dan tentunya hasil pendidikan yang didapatkan tidak berkualitas juga.

Berdasarkan dari paparan masalah-masalah yang dimaksud di atas, maka peneliti merasa perlu mengadakan pembahasan seputar Manajemen Mutu Kompetensi Profesional Pendidik. Peneliti akan membahas hal-hal yang berkaitan dengan pentingnya manajemen peningkatan kompetensi profesional pendidik yang mengacu pada standar yang telah ditetapkan pemerintah lewat Peraturan Pemerintah Nomor 23 Tahun 2013 tentang standar Nasional Pendidikan, Pasal 28 ayat (3) yang mengupas tentang kompetensi profesional pendidik bahwa seorang guru wajib memiliki kualifikasi akademik, kompetensi, dan sertifikat pendidik serta sehat jasmani dan rohani. ${ }^{6}$

Abidin mengemukakan untuk mendapatkan sumberdaya guru yang berkualitas tinggi diperlukan konsep dan upaya strategis pengembangannya. Ada beberapa konsep strategi pengembangan mutu sumberdaya guru yang ditawarkan para ahli. Abidin menawarkan tiga teknik strategi yaitu (1) dengan meningkatkan kecerdasan; (2) meningkatkan kemampuan; dan (3) dengan meningkatkan kesejahteraan. ${ }^{7}$

Selain itu ada dua pendekatan yang ditawarkan oleh Robert Waterman dalam menentukan strategi pengembangan sumberdaya manusia yaitu pendekatan yang dikenal dengan "buy” yaitu pendekatan yang lebih berorientasi terhadap penrikan sumberdaya manusia, dan pendekatan "make" yaitu pendekatan yang berorientasi pada program bimbingan, pelatihan dan pendidikan pada sumberdaya manusia yang ada. ${ }^{8}$ Sementara Sonnenfeld dan Maury Peyperl mengemukakan empat tipologi strategi sumberdaya manusia yaitu: Baseball team, Club, academy, fortress.

Jadi dapat ditarik benang merah bahwa dalam rangka pengembangan dan peningkatan sumberdaya guru di lembaga pendidikan islam diperlukan metode, bentuk, teknik, dan upaya

\footnotetext{
${ }^{6}$ Permata Press PP No 32 Tahun 2013: 2013: 43.

7 Mulyadi, 49

${ }^{8}$ Watermen dalam Nurhayati, Manajemen Mutu Pendidikan, (Bandung: Alfabeta, 2010) 7

${ }^{9}$ Mulyadi, 56
} 
strategis untuk mewujudkan sumberdaya guru yang bermutu dan profesional dan komitmen. Hal itu guna menanggulangi kemerosotan dan penurunan mutu sumberdaya guru yang selama ini menjadi salah satu problem pendidikan islam khususnya madrasah kemerosotan tersebut dalam berimplikasi pada menurunnya kualitas lembaga pendidikan islam (madrasah).

Untuk mengungkap jawaban terhadap persoalan diatas maka peneliti melakukan penelitian tentang "Strategi Pengembangan Mutu Sumberdaya guru di Madrasah Aliayah Negeri 3 Jember"

Salah satu keunikan yang dimiliki MAN 3 Jember adalah mempunyai orientasi masa depan yakni mengerahkan anak didi menjadi generasi yang siap hidup dizamannya; MAN 3 Jember memiliki visi memposisikan madrasah sebagai pusat keunggulan yang mampu menyiapkan dan mengembangkan sumberdaya insani yang berkualitas. Selain itu yang menjadi kelebihan lain di madrasah ini adalah letak geografis yang terletak dipedesaan. Maskipun letaknya terletak di pedesaan tetapi tidak mengurangi semangat kepala sekolah, guru, siswa untuk bisa bersaing dengan sekolah perkotaan. Terbukti dalam tiga tahun terahir MAN 3 Jember banyak mendapat beberapa pretasi, seperti cerdas sermat, MTQ sejatim, dan guru teladan.

Dalam rangka peningkatan kompetensi profesional pendidik seperti diamanahkan oleh undang-undang dan peraturan pemerintah, di MAN 3 Jember, maka diperlukan manajemen untuk mewujudkan sumber daya pendidik yang bermutu, profesional, produktif dan memiliki komitmen yang tinggi. Hal ini untuk menanggulangi kemorosotan dan penurunan kompetensi profesional pendidik yang selama ini menjadi salah satu problema pendidikan khususnya di madrasah. Kemerosotan tersebut dapat berimplikasi pada menurunnya kualitas madrasah.

Berdasarkan uraian di atas tentang pentingnya peningkatan kompetensi sumber daya manusia khususnya pendidik/guru di MAN 3 Jember, maka diperlukan strategi yang matang dan visioner. Apalagi kenyataan dilapangan tantangan yang dihadapi madrasah sangat kompleks, tampak bahwa sebagian besar madrasah belum dikelola secara memadai, untuk mengadakan perbaikan atau upaya peningkatan kompetensi profesional pendidik umumnya masih sangat rendah.

Pendidik berperan besar sebagai motor penggerak (change agent), dan menduduki posisi utama sebagai upaya mewujudkan obsesi madrasah menjadi sekolah unggul. Untuk itu MAN 3 Jember selalu berusaha meningkatkan kompetensi profesional pendidik-pendidiknya. Salah satunya melaksanakan manajemen mutu peningkatan profesional pendidik tebukti dengan tersertifikasinya sebagian besar pendidik di MAN 3 Jember.

Berangkat dari kiat, bentuk, upaya strategis pengembangan, dan komposisi status sumberdaya guru MAN 3 Jember maka sangatlah menarik untuk diteliti. Oleh karena itu peneliti sangat tertarik untuk mengetahui bagaimana strategi MAN 3 Jember mengembangkan mutu 
sumberdaya guru, bentuk dan upaya strategis yang telah dilakukan oleh MAN 3 Jember dalam mengembangkan mutu guru-gurunya, upaya-upaya yang telah dilakukan oleh pimpinan MAN 3 Jember dalam meningkatkan kemampuan para guru dalam pengelolaan proses belajar mengajar demi meningkatkan prestasi belajar murid dan kualitas sekolah.

\section{METODE DAN PROSEDUR PENELITIAN}

Pendekatan penelitian ini menggunakan pendekatan paradigma kualitatif, karena dalam penelitian ini nanti peneliti mencoba untuk menganalisis fenomena yang ada $d \quad$,an, semua peristiwa yang terjadi di linkungan masyarakat, aktivitas sosial, sikap, kepercayaan, persepsi, dan segala bentuk pemikiran orang ataupun kelompok.

\section{PEMBAHASAN}

Berangkat dari perencanaan perlunya pengembangan mutu sumberdaya guru MAN 3 Jember di atas, maka MAN 3 Jember dituntut melakukan beberapa siasat, cara-cara, dan kiat-kiat khusus untuk mengembangkan mutu sumberdaya guru-gurunya.

Dalam hubungan dengan kompetensi guru, proyek pengembangan pendidikan guru telah berhasil merumuskan tiga kemampuan pokok yang harus dimiliki oleh seorang guru. Ketiga mampuan tersebut dikenal dengan "tiga kompetensi” yaitu: (1) kompetensi profesional; (2) kompetensi personal; dan (3) kompetensi sosial. ${ }^{10}$

Dilihat dari pendekatannya Strategi pengembangan mutu sumberdaya manusia dibagi menjadi dua bagian yaitu (1) pendekatan yang dikenal dengan "buy" yaitu pendekatan yang berorientasi penarikan (rekrutmen) sumberdaya manusia; (2) pendekatan yang dikenal dengan "make" yaitu pendekatan yang berorientasi pada pengembangan sumberdaya manusia yang ada berupa pendidikan, pelatihan dan bimbingan ${ }^{11}$.

Dalam pengembangan mutu sumberdaya guru, MAN 3 Jember melakukan beberapa siasat, cara-cara dan kiat-kiat khusus, inilah yang disebut dengan strategi. Strategi pengembangan mutu guru yang dilakukan oleh MAN 3 Jember bertujuan untuk menghasilkan dan membentuk guru yang bermutu tinggi yang memiliki komitmen kuat terhadap lembaga. Dalam pengembangan mutu guru ada beberapa upaya yang dilakukan oleh pimpinan MAN 3 Jember. Untuk menelusuri bntuk dan upaya strategis pengembangan mutu sumberdaya guru. Peneliti mencoba menelusurinya secara periodik yakni mulai dari kepemimpinan mantan kepala sekolah yakni MAN 3 Jember.

${ }^{10}$ Nurhayati, Manajemen Mutu Pendidikan, 18

11 VicentGasperesz, All In One, intregeted tital quality Telet Management. (Jakarta: Gramedia, 2013) 62 
Dalam rangka pengembangan sumberdaya guru langkah awal yang dilakukan oleh para pimpinan MAN 3 Jember adalah dengan (1) membuat, menyusun dan merumuskan visi, misi, dan tujuan lembaga, dari visi misi lembaga tersebut MAN 3 Jember menyusun visi, misi, dan tujuan pengembangan mutu guru secara khusus; (2) membangun komitmen (nilai ibadah); (3) membangun disiplinan para guru; (4) merubah pola pikir guru/membangun karakter positif (positif caracter building) guru dengan cara: (a) pendidikan (education), bertujuan untuk meningkatkan kemampuan kerjanya dalam arti luas; (b) pelatihan, bertujuan utnuk mengembangkan individu dalam bentuk peningkatan keterampilan, pengetahuan dan sikap dan (c) bimbingan serta; (d) kegiatan-kegiatan yang lain yang dapat membantu pengembangan mutu guru

\section{a. Membangun Visi, Misi, Dan Tujuan Lembaga}

Sebagaimana telah diungkap pada latar belakang pengembangan mutu guru terutama dari aspek sejarah dapat diketahui bahwa MAN 3 Jember dengan perjuangan yang cukup panjang menjadi lembaga islam favorid di Jember, yang menjadi tumpuan dan harapan masyarakat. Maka untuk mempertahankan status tersebut maka MAN 3 Jember harus membenahi diri terusmenerus dengan cara, (i) merumuskan visi kelembagaan yang jelas yang menggambarkan kualifikasi ideal kelembagaan MAN 3 Jember yang diharapkan dapat dicapai di masa yang akan datang (ii) merumuskan kelembagaan yang jelas menggambarkan profil madrasah yang menjadi tumpuan harapan masyarakat, (iii) merumuskan tujuan institusional MAN 3 Jember dengan tegas menggambarkan kualifikasi perilaku ideal lulusan yang dihasilkan dan pendidik sebagai tulang punggung keberhasilan proses belajar mengajar, serta (iv) menjadikan visi, misi dan tujuan MAN 3 Jember sebagai landasan filosofis oparasional di dalam perumusan program penyelenggaraan pendidikan maupun kebijakan pengembangan pendidikan.

Menurut kamus bahasa Indonesia, yang dimaksud dengan visi ialah daya ingat, indra penglihatan. Segala yang dapat dilihat orang dari suatu tempat tertentu, kemampuan untuk melihat atau mengetahui sampai pada intinya atau pokok dari suatu hal atau persoalan. ${ }^{12}$ Atau yang disebut visi adalah penglihatan, pandangan, hayal, atau impian. Berdasarkan devinisi tersebut berarti visi adalah suatu pandangan atau gambaran tentang cita-cita kedepan dari suatu persoalan secara mendalam.

Dari visi, misi dan tujuan lembaga tersebut menuntut MAN 3 Jember membenahi mutu unsur tenaga pengajar yang ada dilingkungan MAN 3 Jember, karena bagaimanapun mutu guru terkait erat dengan mutu anak didiknya, karena guru adalah orang yang terkait langsung dengan anak didik. Oleh karena itu dalam memahami mutu tenaga pengajar di MAN 3 Jember pihak pimpinan sekolah berupaya merumuskan arah pengembangan mutu guru-gurunya yang bertuang

12 (Purwodarminto,2007:251) 
dalam visi, misi dan tujuan yang ingin di capai dalam memperdayakan dan meningkatkan mutu guru.

Adapun misi pengembangan mutu sumberdaya guru adalah mendapatkan dan menjadikan guru profesional yang bermutu tinggi yakni guru yang mampu mengatisipasi perubahan zaman, memiliki didikasi, loyalitas, kreativitas dan komitmen tinggi yang dijiwai semangat ibadah dan keikhlasan untuk mengabdi kepada lembaga, agama dan bangsa.

Secara khusus tujuan MAN 3 Jember yaitu memberi bekal kemampuan dasar "baca, tulis, hitung" pengetahuan keterampilan dasar yang bermafaat bagi siswa, memberikan kemampuan dasar tentang agama.

\section{b. Membangun Komitmen Guru.}

Komitmen secara bahasa adalah kontrak; perjanjian untuk melaksanakan suatu. Komitmen yang dimaksud adalah komitmen guru terhadap lembaga yang menyangkut tugas dan kewajibannya sebagai profesional. ${ }^{13}$ Salah satu indikator guru bermutu tinggi adalah guru yang memiliki komitmen yang tinggi terhadap lembaga. Menurut Sri Kamini guru yang memiliki komitmen yang tinggi akan berimplikasi pada mutu sekaligus profesional guru. ${ }^{14}$ Dalam membangun komitmen guru yang dijiwai semangat ibadah, MAN 3 Jember dilakukan beberapa hal, diantaranya dilakukan melalui penjaringan calon guru (orientasi).

Dapat diketahui bahwa upaya pengangkatan guru yang dilakukan kepala sekolah MAN 3 adalah melalui cara yang bersifat informal yakni mengangkat orang-orang yang sudah dikenalnya memiliki mutu, semangat pengabdian dan disiplin yang tinggi, Pengangkatan calon guru yang dilakukan lembaga dengan mengamati secara langsung orang-orang tertentu yang dianggap memiliki kompetensi tertentu dan profesional

Jadi dapat diketahui untuk merekrut guru khususnya guru non dinas di MAN 3 Jember yang diutamakan adalah pertimbangan potensi dan keahlian seseorang, sehingga kemungkinan terjadinya sistem paternalistik sangat dihindari.

Berdasarkan hasil wawancara, dokumen dan observasi maka dapat diketahui bahwa penanaman komitmen melalui orientasi masuk calon dapat diketahui dari tes yang berlapis yang harus dilalui guru baru di MAN 3 Jember yakni melalui empat tahap yaitu: (a) seleksi administrasi; (b) ujian lisan; dan (c) tes secara komprehensif (tes uji coba 3 bulan). Tujuannya diadakan tes terebut adalah untu mendapatkan calon guru yang betul-betul sesuai dengan keinginan dan kebutuhan lembaga.

MAN 3 Jember dalam menerima tenaga guru harus memenuhi tiga syarat, yaitu profesional, berkepribadian baik, dan memiliki wawasan keagamaan (dititik beratkan pada kepiawaian

13 Vicent, All in one. 120

${ }^{14}$ Srikamini, Manajemen Pengelolaan Lembga, 67 
membaca al-qur'an), serta niat yang ikhlas. Hal ini didasari pemikiran bahwa lembaga yang ditangani oleh tenaga yang profesional, institusi tersebut pasti akan menjadi institusi yang maju. Namun MAN 3 Jember juga tidak mengabaikan segi normatif dan sisi religius, mengingat MAN 3 Jember adalah institusi yang berciri khas agama islam. Oleh karena itu kemantapan kepribadian dan wawasan keagamaa serta penanaman nilai ibadah menjadi hal yang sangat penting yang tidak boleh diabaikan.

Dari penjelasan di atas dapat diketahui bahwa latar belakang dilaksanakannya masa uji coba bagi seorang calon tenaga guru adalah untuk mengetahui lima hal yang utama yaitu komitmen, loyalitas, kreativitas, motivasi dan dedikasinya. Dengan mengetahui komitmen, loyalitas, kreativitas, motivasi dan dedikasi maka dapat dengan mudah menilai mutu dan orientasi serta komitmen calon tenaga guru di MAN 3 Jember. Tenaga guru dalam masa ini masih dalam pemantauan, dan penilaian, oleh karenanya apabila dalam masa uji coba tersebut dinilai baik (profesional) dan memenuhi kriteria yang diinginkan oleh pihak lembaga, maka guru akan menerima SK dalam jangka waktu satu tahun pelajaran. Namun begitu sebaliknya apabila dalam masa uji coba dinilai tidak layak dan tidak memenuhi kriteria yang diinginkan oleh pihak sekolah maka akan menerima ucapan terima kasih dari lembaga.

\section{c. Memberi Kesejahteraan yang Mencukupi}

Kesejahteraan sangat erat kaitannya dengan mutu dan kualitas seorang guru. Karena itu pengabdian seseorang harus diimbangi dengan pemberian kesejahteraan. Seorang tidak akan bekerja maksimal sewaktu nilai pekerjaannya tersebut tidak dihargai. ${ }^{15}$ Pemberian kesejahteraan harus diartikan dalam dua kategori yakni secara material dan non material. Kesejahteraan material (misalnya gaji, honorarium, dan fasilitas fisik) dan non material yang mengarah kepada kepuasan kerja. Hal yang perlu diingat adalah bahwa guru adalah orang yang terdidik dan seorang pendidik sehingga kesejahteraan non material seringkali sangat diperlukan.

Kesejahteraan guru dan karyawan adalah hal yang sangat diperhatikan oleh pimpinan MAN 3 Jember. Hal ini berangkat dari sebuah pemikiran bahwa guru akan bekerja maksimal apabila kesejahteraannya terjamin dengan baik. Oleh karena itu ada beberapa upaya yang dilakukan oleh MAN 3 Jember dalam pemenuhan kesejahteraan guru baik kesejahteraan yang bersifat material ataupun non material.

Kesejahteraan yang bersifat material di MAN 3 Jember sangat diperhatikan oleh pimpinan/kepala sekolah, sehingga kepala sekolah dengan dibantu oleh Komite berusaha meningkatkan kesejahteraan guru-guru di MAN 3 Jember, baik guru yang berstatus dinas maupun non dinas dari waktu kewaktu. Kesejahteraan guru dinas berupa gaji selain memperoleh gaji dari Kementri-

\footnotetext{
15 Sri kamini, 88
} 


\section{Model Pengembangan Mutu Sumberdaya Guru}

an Agama juga mendapat tambahan dari Komite yang jumlahnya cukup besar kira-kira setengan dari gaji pegawai negeri bahkan untuk pejabat struktural mendapat tambahan kesejahteraan dari komite. Sementara bagi guru non dinas sepenuhnya digaji/ditanggung oleh komite. Adapun besar gaji yang diterima oleh para guru non dinas tetap mengikuti standar guru pegawai negeri.

Pemenuhan kesejahteraan yang bersifat material guru di MAN 3 Jember terus ditingkatkan dari waktu kewaktu. Pemenuhan kesejahteraan guru MAN 3 Jember dianggap krusial pada kepuasan guru. Guna memenuhi keinginan tersebut dan mengurangi tanggungan yang begitu berat, maka MAN 3 Jember dengan bekerja sama dengan komite mencoba membuat terobosan baru yakni dengan cara mengusulkan guru-guru non dinas (belum dinegerikan) untuk diangkat menjadi guru negeri. Hal ini berkaitan dengan kesejahteraan yang diterima oleh para guru di MAN 3 Jember.

Selain para guru mendapatkan kesejahteraan berupa peningkatan gaji, peningkatan tambahan kesejahteraan guru yang lainnya juga dilakukan oleh sekolah melalui pihak komite, diantaranya adalah sebagai berikut

1. Menaikkan kesejahteraan gaji guru dan pegawai secara berkala baik guru dinas maupun guru non dinas (guru tidak tetap);

2. Memberi tunjangan Hari Raya kepada semua guru dan pegawai dilingkungan MAN 3 Jember ;

3. Mengansuransikan guru dan pegawai yang tetap;

4. Memberikan tunjngan berupa: a) tunjangan nikah; b) tunjangan melahirkan; c) tunjangan sakit; dan d) tunjangan meninggal dunia.

Perlakuan manajemen MAN 3 Jember tersebut dapat ditelaah dari kajian teori rewarding. Pemberian imbalan (rewarding) berupa memenuhan material adalah sebuah kategori perilaku yang menyangkut pemberian manfaat yang berwujud (tangeable) kepada seorang guru kinerja yang efektif, keberhasilan yang signifikan, dan bantuan yang bermanfaat, imbalan yang mungkin dapat diberikan oleh para pimpinan kepada para bawahan termasuk peningktan gaji, rencana kerja yang lebih baik sert penugasan yang lebih baik.

\section{d. Penanaman Disiplin}

Kedisiplinan merupakan salah satu ciri guru yang bermutu. Bagi seorang guru kedisiplinan memiliki arti yang sengat lusa tidak hanya terbatas disiplin waktu datang dan pulang, akan tetapi disiplin mengisi waktu datang dan pukang, disiplin dalam mengikuti program - program pengembangan mutu yang dicanangkan madrasah, berpakaian (sergam), berpperilaku secara islami dan juga disiplin dalam mencapai target pengajaran yang telah ditentukan. ${ }^{16}$ Jadi ke-

16 Abd. Zaky. Kepemimpinan dan Motivasi Kerja, (Jogjakarta:Arruz Media, 2009) 45 
disiplinan seorang guru, meliputi unsur kedisiplinan dalam seluruh tugas dan kewajiban sebagai seorang uru (mengajar, mendidik, dan melatih). ${ }^{17}$

Dalam pengembangan mutu guru penanaman disiplin ini peru adanya, karena bagaimanapun bentuk dan upaya serta program yang diberikan oleh sekolah dalam pemberdayaan guru tidak akan berhasil tanpa adany kedisiplinan yang tinggi dan para aparatur sekolah te rutama oleh guru termasuk didalamnya seoran kepala sekolah dan aparatur sekolah.

Penanaman kedisiplinan di MAN 3 Jember dimulai dari atas yakni kepala sekolah serta struktural. Kedisiplinan yang tinggi di MAN 3 Jember ditanamkan. Kedisiplinan yang ditanamk an oleh para pemimpin diikuti oleh para bawahannya termasuk guru. Kedisiplinan yang ditanamkan di MAN 3 Jember menyangkut segala aspek baik disiplin pribadi (individu), organisasi, program, hal ini terlihat pada kedisiplinanpimpinan dan guru pada waktu datang dan pulang, disiplin mengisi waktu datang dan pulang, disiplin mengisi waktu datang dan pulang, disiplin dalam mengikuti program - program pengembangan mutu yang dicanangkan madrasah seperti rappat, KKG, KKm, kolokium, dikusi, seminar, simposium dan lain - lain, disiplin berpakaian (seragam), berperilaku secara islami dan juga disiplin dalam mencapai target pengajaran yang telah ditentukan.

Sebagaimana telah dijelaskan sebelumnya bahwa kedisiplinan guru - guru di MAN 3 Jember cukup tinggi karena dimulai dai pimpinannya. Pimpinan sebagai seorang top leader tentunya akan dijadikan panutan oleh setiap orang. Demikian juga di MAN 3 Jember. Kepala sekolah sebagai pimpinan tertinggi adalah sebagai pigur yang akan diikuti oleh setiap orang yang ada dilembaga. Untuk itu pimpinan di MAN 3 Jember dituntut menjadi contoh dan inspirasi guru untuk pengembangan mutu guru. Guru sebagai bawahan dari pimpinan akan termotivasi oleh pimpinan untuk meningkatkan kualitas diri manakla pimpinan di MAN 3 Jember terus mencoba membenahi diri dan menjadikan dirinya sebagai motivator bagi para guru. Menurut hasil survei, dan hasil wawancara dan pengakuan dari beberapa guru mereka dituntut disiplin karena pimpinan lembaga sangat disiplin. Kedisiplinan yang dicontohkan kepala sekolah MAN 3 Jember sangat luar biasa misalnya masalah kedisiplinan datang dan pulang, kepala sekolah di MAN 3 Jember datang sebelum guru - guru dan siswa hadir dikelas demikian juga kepala sekolah MAN 3 Jember tidak akan meninggalkan sekolah sebelum semua kelas bersih dan rapi kembali.

\section{SIMPULAN}

Dalam rangka pengembangan sumberdaya guru langkah awal yang dilakukan oleh para pimpinan MAN 3 Jember adalah dengan (1) membuat, menyusun dan merumuskan visi, misi, dan tujuan lembaga, dari visi misi lembaga tersebut MAN 3 Jember menyusun visi, misi, dan tujuan

${ }^{17}$ Abd. Zaky. Kepemimpinan dan Motivasi Kerja, 55

FENOMENA, Vol. 20 No. 1 (Januari - Juni 2021) | 29 
pengembangan mutu guru secara khusus; (2) membangun komitmen yang dijiwai semangat nilai ibadah (3) membangun disiplinan para guru; (4) merubah pola pikir guru/membangun karakter positif (positif caracter building) guru dengan cara: (a) pendidikan (education), bertujuan untuk meningkatkan kemampuan kerjanya dalam arti luas; (b) pelatihan, bertujuan utnuk mengembangkan individu dalam bentuk peningkatan keterampilan, pengetahuan dan sikap dan (c) bimbingan serta; (d) kegiatan-kegiatan yang lain yang dapat membantu pengembangan mutu guru

\section{DAFTAR PUSTAKA}

Aduweisy, Muhammad Abdullah. 2007. Menjadi Guru yang Sukses dan Berpengaruh. Surabaya: Elba. Alwi, Mohammad. 2007. Pegembangan Profesionalisme Guru. Bandung: Diponegoro.

Amidjaja dan Tisna. 2002. Pola Pembaharuan Sistem Tenaga Kependidikan. Jakarta: DEPDIKBUD. Aqib, Zaenal. 2002. Profesionalisme Guru dalam Pembelajaran. Surabaya: Cendikia.

Asiyanto. 2005. Manajemen Produksi untuk jasa produksi. Jakarta: Pradnya Paramita.

Bafadhal, Ibrahim. 2006. Peningkatan Proesional Guru Sekolah Dasar Dalam Kerangka Manajemen Peningkatan Mutu Berbasis Sekolah. Jakarta: Bumi Aksara.

Burhanuddin dkk. 2004. Manajemen Pendidikan. Malang: Universitas Negeri Malang.

Direktorat Pendidikan. 2007. Modul Perencanaan Lembaga. Direktorat Pendidikan: Jakarta

Djamarah, Syaiful Bahri. 2004. Prestasi Belajar dan Kompetensi Guru. Surabaya: Usaha Nasional.

Gasperesz, Vicent, 2013. All In One Intregeted Total Quality, Talent Management, 50 Concepts, Models and Key Analyses in Total Quality, Practical Human Capital, And Talent Managament Sistem. (Jakarta: Publishing)

Hamalik, Oemar. 2004. Proses Belajar Mengajar. Jakarta: Bumi Aksara.

Hidayati, Titiek Rohanah. 2009. Perencanaan Pembelajaran. Jember: CSS.

Kunandar. 2007. Guru Profesional. Jakarta: Raja Grafindo Persada.

Miles, Huberman. 2002. Analisis Data Kualitatif Buku Sumber tentang Metode-metode Baru. Jakarta: UI Press.

Mulyasa. 2005. Menjadi Profesional Menciptakan Pembelajaran Kreatif dan Menyenangkan. Bandung: PT:

Remaja Rosdakarya.

Nurdin, Muhammad. 2004. Kiat Guru Profesional. Yokyakarta: Ar-Ruzz Media.

Peraturan Pemerintah Nomor 23 Tahun 2013 tentang standar Nasional Pendidikan, Permata press.

Raharjo, Budi. 2009. Biografi Ki Hajar Dewantoro. Jogjakarta: Arruz Media

S. Arcaro, Jerome. 2007. Pendidikan Berbasis Mutu: Prinsip-Prinsip Perumusan dan Tata Langkah Penerapan, Terj. Yosal Irianta. Yogyakarta: Pustaka Pelajar.

30 | FENOMENA, Vol. 20 No. 1 (Januari - Juni 2021) 
Sallis, Edward. 2006. Total Quality Management in Education: Manajemen Mutu Pendidikan, Terj. Ahmad Ali Riyadi dan Fahrurrazi. Yogyakarta: IRCISOD.

Sukmadinata, Nana Syaodih. 2010. Metode Penelitian Pendidikan. Bandung: Remaja Rosdakarya. Undang-Undang No. 20 Tahun 2003, tentang Sistem Pendidikan Nasional. Jakarta: Depdiknas. Uwes S. 2009. Majemen Pengembangan Mutu Dosen. Jakarta: Logos Wacana Ilmu.

Winoto, Suhadi. 2011. Manajemen Berbasis Sekolah. Jember: Pena Salsabila. 
